\title{
CUMHURIYIT DEVRINDE 1981'E KADAR ÖZEL EĞITIM
}

\author{
Doc. Dr. Doğan CAGLAR
}

Yll 1981 ulu önderimiz Atatürk'ün doğumunun 100. yılı. Bu yılı yalnız biz değil, dünya Atatürk yılı olarak kabul ve ilan etti. Birkaç ülke hariç dünya milletleri ulu önderimiz Atatürk"ün anısına toplantılar düzenliyor, fikirlerini ve yaptıklarını tartıșıyor. Çünkü Atatürk' yalnız Türk milletinin kurtaricısı ve Türkiye Cumhuriyetinin kurucusu değildir. $O$, bağımsızlıklarını kaybetmiş ülkelerin bağımsızlıklarını kazanmalarında izlenecek yolları çizen ve eylem olarak gösteren rehber liderdir. $O$, insanlar arasında barışa içtenlikle inanarak "Yurtta Sulh, Cihanda Sulh" özdeyişini ulusal ve uluslararası düzeyde izlenmesi gereken temel politika olarak ilk vurgulayan devlet adamıdır. O, birçok içten, inançl özdeyișleri ve bunlara uygun eylemleri ile dünyanun hayranlığını kazanmıș nadir devlet adamlarindan biridir ve hatta tek liderdir demek abartma olmaz. $O$, sözlerile değil her söylediğini yaparak önder olmuștur. Savașta onu izleyenler sonu ölümle noktalanacak bir yolculuğa severek çlkmișlardı. Çünkü, en önde, o vardı. "Siz cennete ben memlekete" diye askerlerin arkasinda yer almadı. Kurtuluș savașinı planlarken en tehlikeli girişimlerde, o önde idi, en çok çalışıp çabalayan o idi. Ulu önderimiz Aitatürk "Herșey millet içindir" özdeyișini yaşamı boyunca ve sonunda eyleme dönüștüren TEK DEVLET ADAMIDIR.

Atatürk, Victor Hügo'nun büyük eseri Sefiller'inde hayalinde canlandırdığı görüşün tek örneği ve simgesi olmuștur. Örnek insan, ulu önderimiz Atatürk yaşami boyunca sahip olduğu kol düğmesinden çiftliklerine kadar herşeyini gerçekten sevdiği milletine vermiştir. Atatürk inanmadığı, yapamayacağı, yapılamayacak hiçbir söz etmemiştir. Atatürk gerçekleri olduğu gibi gören ve her dediğini eyleme dönüștüren yüce bir Türk devlet adamıdır. 


\section{CUMHURIYET DEVRINDE 1981'e KADAR ÖZEL EGITTIM}

Ulu önderimiz Atatürk eğitimle ilgili birçok üstün görüșler ve çă̆daş ilkeler geliştirmiștir. Ancak bunlarn çoğunu eyleme dönüștürmeye yașamı yetmemiştir. Çünkü, eğitime ilişsin görüșlerin uygulamaya dönüștürülmesi ve ürünlerin alınması en az 20 yıl almaktadır. Atatürk, eğitimi, Türk Ulusunu Çăgdaș Uygarlık düzeyinin üstüne çıkaracak en güçlü bir arą olarak görmüștür. Eğer Atatürk'ün yașam süreci onun eğitim görüşlerini eylemlere dönüştürmeye yetseydi o zaman Türkiye, Atatürk'ün Türkiye'si olabilirdi.

Atamız eğitime inanç ve güvenini 1921 de söylediği sözlerle şöyle açılıyor. "Bugün, eriştiğimiz nokta, hakiki kurtuluṣ noktası değildir. Kurtulus için bilim gerekir, teknik gerekir. Bilim ve teknik, okulda kazanılır. Eğitim okul demektir. Okul, insanlığa saygıyı, ulusa ve ülkeye sevgiyi ve ịstiklalin șerefini öğreten kutsal bir yerdir". 1925 yılında ise "Eiğitimdir ki, bir ulusu, hür, bağımsız, șanlı ve yüksek bir toplum halinde yaşatır; veya bir ulusu kölelik ve yoksulluğa terkeder". Bu onun ne kadar derin ve engin bir ileri görüșe sahip olduğunu göstermektedir. O dehanın eğitime ilişkin bu inancinı eyleme dönüștüren birçok ülkeler ürünlerini de alarak beklenen g'elișimi sağlamıșlardır.

Buraya kadar Atatürk ve onun eğitime olan inancından kısaca bahsettik. Şimdide Atatürk'ün özel eğitimle ilgili görüşlerini açılamak isterim. Okurlarım biraz sonra yazacağım Atamıin özdeyişinde özel eğitim ile bir kelime dahi göremeyecekler ve belkide özel eğitimle bu özdeyiş arasında 'bir bağintı kuramayacaklardır. 1963 yllına kadar bende bu özdeyișteki yüce anlamı ve inceliği keşfedemiyenlerdendim. Atatürk toplumu her zaman bir bütün olarak görmüș. Durumları ne olursa olsun toplumu olusturan bireyleri, hic bir zaman toplumdan soyutlamadan, onları smiflandırmadan bütünün ayrılmaz bir parçası olarak görmüștür. "İmtiyazsız sınıfsız kaynaşmıș bir kitleyiz" deyimi onun bu konudaki inancinin aynasıdir: Ulu önder Atatürk'ün özel eğitimin gereğini içeren özdeyiși șöyledir: "Bizim izleyeceğimiz kültür politikasınn temel amacl, önce mevcut bilgisizliği ortadan kaldırmaktır. Bunun için, ülkede, kızerkek, okuyup yazma bilmeyen tek vatandaş kalmayacaktır". Atatürk'ün, eğitim görüşünde odaklaşan ilkelerden en önemlisi tüm halkın eğitilmesidir. O'na göre eğitim sadece elit bir zümrenin tekelinde olamaz. Ulusun bütün bireyleri eğitim olanaklarindan yararlanmalı; eğitim tabana indirilmeli, herkes eğitilmeli ve bilgisizlik bütün yurt düzeyinde, kökünden yok edilmelidir. Ulu önder Ata- 
türk'ün 1925 lerde koyduğu bütlinlük (herkese eğitim) ilkesi gelişmiş diye nitelediğimiz ülkelerin eğitim uygulamalarına 1950 lerden sonra girmiștir. "Herkes için eğitim" (Education for all) şeklinde sözlendirilip yepyeni bir ilke gibi uygúlamaya bașlanmıștır.

Atatürk, eğitimi toplumu olușturan her bireyin doğal ve temel bir hakkı olarak görmüștür. Sakat-sağlam, fakir-zengin, kız-erkek, anall-babalı-kimsesiz, olmasina bakılmasızın her vatandașın eğitilmesini toplumsal bütünleșmenin ve toplumca kalkınmanın ilk gereği olarak görmüștür. Hatta herkes için eğitim derken özel eğitime muhtaç-özürlï insanlarm eğitimine ayrıca değinmeyi toplum anlayıșına, insanlık anlayıșina ters düșen bir durum olarak görmüștür. Onları da toplumda eşit haklara sahip olan, toplumun saygıdeğer kișileri olarak kabul etmiş, onlar ayirt etmek aklından bile geçmemiștir. Ama toplumu oluşturan bütün bireylerin eğitilmesi gerektiğini birçok söylevlerinde vurgulamiștır. Bu yüce ve olgun görüș 1981 lerde dahi çok gelişmiş ve uygar olarak nitelediğimiz ülkelerin çoğu tarafindan bu düzeyde benimsenmemiştir.

Ulu önder Atatürk'ün 1925 lerde koyduğu "Herkese eğitim verilmesi" ilkesi ülkemizde içtenlikle uygulamaya başlanmış olsa ve ülkenin mali olanaklarmın elverdiği oranda devam ettirilseydi, buğün 1981 yllında dünyanın en uygar ülkeleri arasında yerimizi almıș olurduk. Çünkü, bugün bir ulusun uygarlık düzeyi o ülkenin özel eğitime muhtaç çocuklara sağladığı eğitim olanakları ile ölçülmektedir. Biz'O'nun yüce görüsslerini uygulamadığımız için bu konuda çok yaya kaldık. Hatta toplumun ayrılamaz bir parçası olan özel eğitime muhtaç kimseleri Atatürk'ün koyduğu ilkelere taban tabana zid düșecek biçimde toplumda 2. ve hatta 3. sınuf kimseler olarak gördük ve eğitim haklarını kısıtladık. Bu hususu bundan sonra açıklayacağı.

\section{OZLL EĞITTM}

Yazimizın bu kısmında asıl konumuz olan özel eğitim nedir, özel eğitime muhtaç birey kimdir? Özürlerine göre bunların tanımları ve bilimsel bir sinflandırilması yapllacak ve ókuyuculara alanın kapsamina giren özürler tanitlacaktır.

\section{Özel Eğitim Alanı Ille Ilgili Tanmmlar ve Temel Kavramlar}

1. Özel Eğitim (ÖE): Özel eğitime muhtaç çocukların eğitimleri için özel olarak yetiştirilmiş personel; geliştirilmiş eğitim prog- 
ramları ve bu çocukların özür ve özelliklerine uygun eğitim ortamında sürdürülen çalışmalara özel eğitim denir.

Burada vurgulanan özel eğitimin üç niteliğini belirtmekte yarar vardir.

a) Özel yetișmiş personel

b) Özel olarak geliştirilmiș eğitim programları

c) Özel şekilde düzenlenmiş eğitim ortamı.

Bunlar sağlanmadığı takdirde özel eğitimden söz etmek yerinde olmayacaktır.

2. Özel Eğitime Muhtac Cocuk (ÖEMÇ): Bedensel, zihinsel, ruhsal, duygusal ve sosyal özelliklerinde, belli bir oranda, sürekli olarak yeti ve işlev kaybı nedenile normal eğitim hizmetlerinden yeterince yararlanamayacak durumda bulunan çocuk özel eğitime muhtaç çocuktur.

Özel eğitim alanının kapsadığı özürleri bedensel, zihinsel, sosyal, öğrenme özellikleri ve birden fazla özürleri yönünden olmak üzere beș ana başlik altında inceleyebiliriz.

\section{Redensel Özellikleri Yönünden ÖEMC}

\section{Görme öziirliuler:}

a. Kör: Bütün düzeltmelere rağmen iki gözle görmesi $1 / 10$ dan așaği olan, eğitim ve öğretim normal yașam ve çalışmalarında görme gücünden yararlanılmasına imkan olmayana "kör" denir.

b. Az gören: Bütün düzeltmelere rağmen iki gözle görmesi $3 / 10$ dan aşağı olan, özel bir takım araç ve yöntemler kullanmadan eğitim ve öğretim normal yașam ve çalışmalarında görme gücünden yararlanamayana az gören denir.

\section{2. İșitme Özưrluler:}

a. Sağır: Bütün düzeltmelere rağmen işitme kayb 90 desibelden daha fazla olan — eğitim ve öğretim - normal yaşam ve çalışmalarında işitme gücünden yararlanamayana sağır denir.

b. Ăgur işiten: Bütün düzeltmelere rağmen ișitme kaybı 25-90 desibel arasında olan, --eğitim öğretim-normal yaşam ve-ça- 
lışmalarında işitme gücünden ancak yardımcı araçlarla yararlanabilene ağır işiten denir.

\section{Konuşma Özürlü:}

Konuşmanın akıșinda, ritminde tizliğinde, vurgularında, ses birimlerinin çıkarılıșında, eklemlenișinde (artikülasyon) ve anlamında bozukluğu bulunana kronuşma özürlü denir.

\section{Ortopedik Öziurlï:}

Bütün düzeltmelere rağmen iskelet, sinir sistemi, kas ve eklemleri, eğitim ve öğretim -normal yaşam ve- çalışmalarında yeteri kadar yararlanılamayacak ölçüde sakatlanmıș olana ortopedik özürlü denir.

\section{Sürekli Hastalığı Olan}

Sürekli bakım veya bakım ve tedavi gerektiren hastallklar nedeni ile, eğitim ve öğretim —normal yașam ve- çalıșmalarında özel önlemlere ihtiyaç gösteren kimse sürekli hastalığı olan kimsedir.

\section{Zihin Özellikleri Yönünden öEMC̣:}

1. Üstün Olanlar

\section{a. Üstuin zekalllar:}

Seçin yeteneklerinden dolayı yüksek seviyeli iş yapmaya yeterli olduğu profesyonel olarak nitelenen kimseler tarafindan belirlenmiş kimsedir. Bu çocuklar kendileri ve toplum için gerekli yardımları gerçekleștirmek için normal okul programlarının sağladığı hizmetlerin ötesinde özel hizmetleri, konuları içeren farklı eğitim programlarının yapılmasını isterler. Kısaca,

Zeka bölümleri, çeșitli ölçülerde, sürekli olarak 130 ve daha yukarı olana üstün zekalı denir.

\section{b. Ưstün Özel Yetenekliler:}

Zeka bölümü çeşitli ölçeklerde sürekli olarak 120 ve daha yukarı olupda güzel sanatlar, matematik, fen ve teknik gibi belirli 
alanlarda yaşıtlarından belirgin ölçüde üstün olana üstün özel yetenekli denir.

\section{c. Geri Zekalılar:}

Doğumdan önce, doğum surasinda ve doğumdan sonraki gelișim süresinde olușan çeșitli nedenlerle, psiko-devimsel (motor) Zihin ve sosyal gelișim ve fonksiyonlarinda sürekli yavaşlama, duraklama ve gerileme sonucu olarak akranlarından dörtte bir ve daha yüksek oranda gerilik gösterenlere geri zekalı denir.

Bunları üç alt grupta görmek mümkündür.

1. Eğitilebilir geri zekalı (EGZ):

Zeka bölümü çeșitli ölçeklerde sürekli olarak 45-75 arasında olana EGZ denir.

2. Öğretilebilir ıgeri zekalı (ÖGZ):

Zeka bölümü çeşitli ölçeklerde sürekli olarak 20-44 arasında olana ÖGZ denir.

3. Ağır derecede geri zekalı (ADGZ) :

Zeka bölümü çeşitli ölçeklerde sürekli olarak 0-19 arasında olana ADGZ denir.

\section{Ruhsal ve Sosyal Uyum Özellikleri Yönünden ÖEMC̣:}

1. Ruhsal ve duygusal uyumsuzluğu olan:

Duygusal güçlükleri nedeni ile kendi gelişimleri engellenen, diğer insanlarla ilișkileri zorlașan ve bu nedenle olağan eğitim hizmetlerinden yararlanması 'imkansızlașan ve özel önlemler alındığı zaman eğitim alacak durumda bulunanlara ruhsal ve duygusal güçlüğü olan denir.

\section{Sosyal uyumsuzluğu olan:}

Bunları da üç grupta görebiliriz.

a. Suça yönelen çocuklar:

Davranışları, sosyal çevreleri, ana ve baba tutumları, kișisel özellikleri nedeni ile suç işlemeye yatkın veya suç ișleme tehlikesinde bulunana, suça yönelen çocuk denir. 
b. Suclu cocuk:

Türkiye Cumhuriyeti ve diğer ülkelerin yasalarina göre suç sayılan davranıș ve tutumları gösteren ve yapana suçlu çocuk denir.

\section{c. Korunmaya muhtac cocuk:}

Çeşitli nedenlerle bedensel, ruhsal, sosyal, duygusal ve moral (ahlâk) gelisimi tehlikede bulunan kimseye korunmaya muhtaç çocuk denir.

\section{IV. Öğrenme Özellikleri Yönünden ÖEMÇ:}

\section{Kültiürel yoksunluğu olan cocuk}

Genel zeka düzeyi yönünden hiç bir özürü ve ayrıcalığı olmamakla beraber, yetiştiği çevrenin nesnel ve kültürel yoksunluğu yüzünden eğitim ve öğretim için gerekli güdüleri, ilgileri ve yașantiları bulamayan kimseye kültürel yoksunluğu olan cocuk denir.

\section{Diğer öğrenme güiçliikleri olanlar}

Organsal ve görevsel nedenlere bağlı özel nitelikte anlama, olkuma , anlatma, yazma, çizme, matematik, tanıma, kavramlaştırma ve benzeri öğrenme güçlï̆̆ü olan kimselerdir.

\section{Birden Fazla Özuirleri Nedeniyle öEMÇ'lar}

Bunlar yukarda sayllan ve tanimlanan birden fazla özürleri olanlardır. Örneğin kör-sağır, sağir-geri zekalı, sağır-özel yetenekli, kör-özel yetenekli, ortopedik özürlü-konușma özürlü vb. U̇lkemizde özel eğitime muhtac çocuklamn okul nüfusundaki oranları $\% 14$ olarak tahmin edilmektedir. Bu tahmini orana göre 1981 yılında 0-18 yaş grubunda 3.046.680 çocuk olduğu söylenebilir. Bunlardan ancak 30.000.000 kadarı eğitim olanaklarına kavușmuștur. Bu tüm öEMÇ'ların yaklaşık olarak \% 1 idir.

\section{Cumhuriyet Devrinde Özel Eğitime Muhtac Cocuklara Sağlanan Eğitim Hizmetleri}

ÖEMÇ'lar için Cumhuriyet devrinden önce de birçok büyük hizmetler sağlanmıștır. Özellikle Enderun okullarında üstün zekalılar ve üstün özel yetenekliler için dünyanın en mükemmel eğitimi ya- 
pılmıștır: Ayrıca Darüleytamlar vd. kurumlarda kimsesiz, șehit çocukları ve korunmaya muhtaç çocuklar için çok yönlü büyük hizmetler yapılmıștır. Bu yazımdaki tarihçe bilgisi daha ziyade bundan önceki kısımda verilen sinfflandırmadaki siraya uyarak sadece Cumruhiyet devrinde özel eğitime muhtaç çocuklar için sağlanan eğitim olanaklarının bir özeti olacaktır.

Bu kısım, ulu önder Atatürk'ün önemle üzerinde durduğu "Herkese Eğitim Ilkesinin" özel eğitime ne zaman, nasıl, ne düzeyde yansıdığının bir göstergesi olacaktır.

Şimdi özel eğitime muhtaç çocuklar için Cumhuriyet Döneminde sağlanan eğitim olanaklarını sinıflandırmamızdaki sıralamaya göre açılklamaya çalışalım.

\section{Görme Özürrlülere Sağlanan Eğitim Olanakları}

Görme özürlülerden ancak körler için eğitim olanakları sağlanmış, az görenler için hiç bir öğrenim olanağı sağlanmamiştır. Ancak az görenlerden başvuranların çoğu kör sayılarak körler okullarında onlarla birlikste eğitime alınmışlardır.

Şimdi körler için sağlanan eğitim olanaklarını tarih akıșına göre görelim.

Türkiye de körler için ilk okul, 1889 yllnda Istanbul Ticaret Mektebinde sağırlarla birlikte açılmıștı. Bu okul önce okul Müdürü Grati Efendi sonrada oğlu Lui Grati tarafindan yönetilmiști. Bu okul 1919 yılında kapatılmıștı.

Bundan sonra 2. girişim 1921 de Izmir'de özel bir dernek tarafından olmuş ve "Sağır-Dilsiz ve Körler Okulu" kurulmuștur. Burada da körler ve sağırlar birlikte eğitim ve öğretim görmüştür.

T.B.M.M. nin himayesinde Izmir'de Körler ve Sağırlar Okulu 1923 te açılmıștır. İlk müdürü kendisi sağır olan ve İstanbul Sağırlar ve Körler okulu mezunu Ali Fuat Bey olmuștur. İkinci așamada okul 1924 yllında Sihhat ve Içtimai Muavenet Vekaletinin (Sağlık ve Sosyal Yardım Bakanlı̆̆1) sorumluluğuna verilmiştir.

Bu okulda körlerin eğitimi 1951 yılına kadar sağırlarla birlikte yapılmıștır. 1951 yılında TBMM. tarafından çıkarılan 5822 sayılı kanunla Milli Eğitim Bakanlığına devredilmiștir. Aynı tarihte körler sağırlardan ayrılarak 1951 yılında Ankara'ya nakledilmiștir. Gerçek 
anlamda körler, bağımsız ve ayrı bir körler okuluna 1951-1952 öğretim yılında Ankara-Etimesğutta açlan okulla kavușmuştur. Bu okul 1952-1953 öğretim yılında Gazi Eğitim Enstitüsüne bağlı Beden Eğitimi Yüksek Okuluna nakledilmiștir. Bu okul bugün körler ortaokulu olarak Ankarada etkinliğini sürdürmektedir.

Ankara da açlan körler okulu önce altı sınıflı ilkokul olarak bașlamış sonra üç yll süreli ortaokul ve gene bu düzeyde üç yll süreli orta sanat bölümünüde içeren ilk ve ortaokul olarak geliştirilmiştir.

Türkiye de 2. körler okulu Aralik 1954 de Gaziantep'te açılmıștır. Sonra ayni ilin Karşıyaka semtinde Devlet tarafindan yeni modern bir körler okulu binası yaptırılmış ve okul bu binaya taşınmıştır. 1967 yılında Gaiziantep Körler Okulunda da ortaokul kısmi açılmıștır. Türliiye'nin üçüncü körler okulu 1971-1972 öğretim yllnda İstanbul-İstinye de Recaizade Fkrem İkokulunun I. binasunda açılmıştır. 1976 yılında bu okula devam eden kör öğrencilerin bir kısmı normal okullara devam ettirilmek suretile sosyal bütünleșme öğretim denemesine bașlanmıș ve devam ettirilmektedir. Ilk denemelerinden iyi sonuçlar alındığı söylenebilir.

Dördüncü körler okulu 1972-1973 öğretim yılında Izmir-Bornova da Yetiștirme Yurdu olarak kullanılan eski bir binada açılmıştır. 1977 yılında yeni binasi tamamlanınca oraya tașınmıştır. Yalnız ilkokul kısmı vardır.

Türkiye'nin beşinci körler okulu 1973-1974 ögretim yılında Ankara Aydınlıkevler de açılmıștır. Ancak bu okulun açılması ile Gazi Ëğitim Enstütüsü yanında 1952-1953 yllnda açlan körler okulu sadece ortaokul olmuş ve ilk kıșmı Aydınlıkevler de yapılan yeni körler okuluna taşınmıştır.

1960-1961 öğretim yllında İstanbul'da bulunan körlerin evlerine en yakın normal ilkokullara devam etmelerini sağlayan "Gezici Öğretmenlik" denemesine başlanmıștır. Bu deneme çalışmalarını yapmak üzere körlerin eğitimi konusunda yurt içinde ve Almanya da özel eğitim görmüş bir öğretmen görevlendirilmiştir. Ancak bu deneme 2 yll sürdürülmüştür.

1973 yllında İstanbul'da yetişkin körler için bir Rehabilitasyon Merkezi açlmıștır. O zamandan beri 6 aylık devrelerle yetișkin körlere rehabilitasyon hizmetleri sunmaktadır. 
1980 yılında Tokat'ta altıncı körler okulu açılmıștır. Fakat etkinliğge geçememiștir. 1980-1981 öğretim yllnda Türkiye'de 6 körler okulu körlere hizmet vérmektedir. Bunlardan 4'ü ilk, biri orta, biri hem ilk ve hemde orta öğretim düzeyinde eğitim öğretim yapmaktadir.

Tüm körler okulları 1957-1958 öğretim yllında hazırlanan "Körler Okulu ve Yetiştirme Yurdu İç Yönetmeliği”ne göre yönetilmektedir. İlk ve orta öğretim için müfredat programı da bu yönetmelikte yer almıștır. Oldukça kısır ve çağ gerisinde kalan bu programın çağdaş düzeye getirilmesi için 1976 yll Haziran ayında program geliștirme çalışmaları yapilmıștır. Onu izleyen yıllarda bu konuda bir çalıșma yapilmamıștır. Ancak bu çalıșmaların 1981 yılında tamamlanması planlanmıștır.

İstanbul-İstinye Körler Okulunda körler için eğitim ve öğretim araçlarının bir kismı yapılmaya başlanmıştır.

Ayrıca Ankara da hem ilk ve hemde ortaokulda Braille Yazısı ile kitap basan iki matbaa makinesi vardır. Bunlar tüm körler okullarinın kitap ihtiyacını karşlamaktadırlar.

\section{Işitme Özürlülere Sağlanan Kğitim Olanakları}

Ișitme özürlülerden ancak işitme kaybı $90 \mathrm{~dB}$ ve daha yüksek olan sağırlar için özel eğitim olanakları sağlanmıș, ağır işitenler içîn özel eğitim önlemleri alınmamıștır. Ama sağırlar okuluna tam sağır olarak alınan öğrencilerin birçoğu ağır işiten durumundadır.

Şimdi sağırlar için sağlanan eğitim olanaklarını tarihi akıșa göre açiklamaya çalışalım.

Türkiye'de ilk sağırlar okulu —Körler kısmında da açıklandığı gibi- 1889 yllnda İstanbul Ticaret Mektebinde Grati Efendi tarafından açılmıștır. Bu hem körler hemde sağırlarin karışık eğitim öğretim gördüğü ilk okuldur. Grati Efendinin ölümünden sonra oğlu Lui Grati bu eğitimi devam ettirmiştir. $\mathrm{O}$ zaman bu okul gündüzlü idi ve 6 ilâ 20 yaş arasinda sağır çocuklar ve gençler aliniyordu. İșaret metoduna göre eğitim yapilyyordu. 1926 yilında bu okul kapatılmıș ve öğrencileri İzmir Sağırlar Okulu'na nakledilmiștir.

Cumhuriyetin ilk yllında, TBMM'nin himayesinde, 1923 yllında İzmir'de 2. sağırlar okulu açılmıstır. Bu okula ilk müdür Istanbul 
sağırlar okulundan mezun kendisi sağır olan Ali Fuat bey olmuştur. Bu okul 1924 yılında Sihhat ve Içtimai Muavenet Vekaletinin (SSYB) sorumluluğuna verilmiștir.

Okulda ilk olarak oral-sözlü öğretim metodu uygulanmıştır. Kültür derslerinin öğretimine ek olarak bu okulda çorapçılık, kundurac1lık, terzilik, doğramacılık vb. sanat çalıșmalarına da yer verilmiș ve bu konuda çok başarılı olunmuştur.

Bu okul, 1951 yılında kabul edilen 5822 sayll kanunla Milli Eğitim Bakanlığına devredilmiştir. O zamana kadar körlerle birlikte yapılan eğitim ayrılmış, körler Ankara da Etimesgutta açılan ayrı körler okuluna nakledilmiştir.

İkinci sağırlar okulu İstanbul da "İstanbul Sağır, Dilsiz ve Körler Tesanüt Cemiyeti" tarafindan 1944 yllında "Istanbul Özel Sağır Dilsiz ve Körler Okulu" adı ile açılmıștır. Bu okul adındanda anlaș1lacağı üzere özel bir okuldur. Okul 1952-1953 ögrretim yllına kadar özel okul olarak öğretimini sürdürmüss 1953 yllında Milli Ëğitim Bakanlığına devredilmiștir. Okul Milli Eğitim Bakanlığına devredildikten sonra Yıldız semtindeki bugünkü yerine nakledilmiștir. Adı da "Istanbul-Yıldız Sağırlar Okulu ve Yetiștirme Yurdu" olarak değiştirilmiştir.

Istanbul Yıldız Sağırlar Okulu 1964-1965 öğretim yılında ilkokula ek olarak ortaokul ve orta sanat kısımları açılmış ve bu düzeyde eğitim öğretime başlanmıștır.

Ưçüncü Sağırlar Okulu 1952-1953 öğretim yılında Ankara Etimesğutta açlmıştır.

1951-1952 öğretim yılında Ankarada o zaman Kız Teknik Yüksek Öğretmen Okulu ve bugün Zübeyde Hanım Kız Meslek Lisesi olan binada "Özel Eğitim Ana Okulu" açılmıştır. Bu okul gündüzlü olarak Ankara da bulunan sağır ve ağır işiten çocuklar için etkinliğe bașlamış ve iki yıl sonra kapanmıștır. Bu, sağırların okul öncesi eğitiminde ilk ve son çalışma olmuștur. O zaman sağırlar okullarında ve ana okulunda görev alan öğretmenler seçilip en az üç aylık sıkı ve uygulamalı bir eğitim aldıktan sonra bu okullara atanmışlardır.

Ankara sağ̣̣lar okulu ve yetiștirme yurdu'da 1969-1970 öğretim yılında ortaokul kısmı da açılmıștır. 1980-1981 öğretim yılında Türkiye'de 17 yatılı Sağırlar Okulu ve Yetiștirme Yurdu bulun- 
maktadır. Bunların yerleri ve açılıș sırası tarihleri aşağıdaki gibidir.

Sura No Okulun Bulunduğu Yer

Açldı̆̆ Öğretiom Yll

\begin{tabular}{|c|c|c|c|}
\hline 1 & Izmir - Alsancak & $(1923-1924)$ & $1951-1952$ \\
\hline 2 & Istanbul - Yilduz & (1944) & $1952-1953$ \\
\hline 3. & Ankara & & $1951-1952$ \\
\hline 4 & Diyarbakır & & $1956-1957$ \\
\hline 5 & Adana : & & $1962-1963$ \\
\hline 6 & İstanbul - Göztepe & & $1969-1970$ \\
\hline 7 & Erzurum & & $1970-1971$ \\
\hline 8 & Konya & & $1970-1 \overline{9} 71$ \\
\hline 9 & Samsun & & $1970-1971$ \\
\hline 10 & Eskişehir & & $1971-1972$ \\
\hline 11 & Sivas & & $1972-1973$ \\
\hline 12 & Kastamonu & & $1974-1975$ \\
\hline 13. & Malatya & & $1974-1975$ \\
\hline 14 & Bursa - Kemal Paşa & & $1976-1977$ \\
\hline 1.5 & Kayseri - Develi & & $1976-1977$ \\
\hline 16 & Çanakkale - Gelibolu & . & $1976-1977$ \\
\hline 17 & Gümüșhane - Şiran & & $1980-1981$ \\
\hline 18 & Rize & & $1981-1982$ \\
\hline 19 & Niğde & & $1981-1982$ \\
\hline \multicolumn{2}{|c|}{ Normal sinıflarda 41 özel sınıf } & & $1981-1982$ \\
\hline
\end{tabular}

Sağırlar okullarında cumhuriyetin ilk yıllarında düzenli bir müfredat programı yapılmamıștır. Yalnız okularda çeșitli sanat. öğretimine ağırlık verilmiștir. Özellikle tzmir Sağırlar ve Körler Okulunda terzilik, kunduracılık, çorapçılık vb. işkollarında iş piyasasında başarll kimseler yetiștirmişlerdir. Okulda oral metotla öğretim ya. pılmıștır. Bugünde tüm okularda oral metotla öğretim yapılması istenmektedir. Ancak bu konuda bașaril olduğumuz söylenemez.

Sağırlar okulunda bugün uygulanmakta olan Sağırlar Okulları Yönetmeliği ile "Sağırlar ilkokulu ve Yetiștirme Yurdu Müfredat Programı" 1967 yılı Haziran ayında Ankara da Doğan Çağlar'ın yönetmeliğinde toplanan Izmir Sağırlar Okulu Müdürü Muhittin Kara- 
han, İstanbul Sağırlar Okulu Müdürü Hitmet Sayın, öğretmen Melek Gönen, Hakkı Gönen, Cahide Oran, Ankara Sağırlar Okulu Müdürü Mustafa (Sancilı) Gürpinar ve öğretmen Mehmet Okuturlar tarafindan hazırlanmiștır. Müfredat programı 5 Eylül 1967 tarihinde kabul edilerek ve onaylanarak uygulamaya konmuştur. Yönetmelik ise 2 Şubat 1967 tarihinde kabul edilerek yürürlüğe girmiştir. 1975 Eylüil ve 1976 Haziran aylarında Sağırlar Okulları Müfredat Programı geliștirme çalıșmaları yapılmıș fakat Milli Ĕğitim Bakanlığı Talim ve Terbiye Dairesinde incelenip sonuçlandırılmamıștır.

Bugün yürürlükte bulunan yönetmelik hükümlerine göre sağırlar okulu öğrenim süresi; 2 yllık ana kısmı, 6 yıllık ilkokul kısmı, 3 ylllık ortaokul kismı ve 3 yıllik orta sanat kısmndan oluşmaktadr. Ancak bunlarda 2 yılık hazırlık kısmı uygulama olanağı bulamamıștır. Ortaokul kısmı ile orta sanat kısımları da 1964-1965 öğretim yılında İstanbul-Yıldız, 1969-1970 öğretim yılında da Ankara Sağırlar Okulunda açılmıştır. Diğerleri sadece 6 yıllık ilkokul olarak çalıșmaktadur.

Konuşma özürlï çocuklar için düzenli hizmet veren bir okul yoktur. Ancak 17 ilimizde etkinlik gösteren Rehberlik ve Arașturma Merkezlerinde teşhis ve sağaltım çalışmaları yapılmaktadır.

\section{Ortopedik Özürlïler Ị̇in Sağlanan Eğitim ve Öğretim Olanakları}

Ortopedik özürlü çocuklardan bir kısmı normal okullara devam etmektedir. Ancak normal okullara devam etmesi mümkün olmayan ortopedik özürlü çocuklar için Milli Eğitim Bakanlığ 1967 yllında bir okul açmaya karar vermiştir. Plan ve projeleri hazırlanıp 1973 yill sonunda yapımı tamamlanan okul Ankara-Aydinlıkevlerde 9 Mart 1974 yılında 38 öğrenci ile öğretime açllmıstır. Önce ilkokul olarak ögretime başlayan okul 1975-1976 öğretim yılında ortaokul kısnı da açmıș ve adı "Ortopedik Özürlü Çoculklar Temel Ë̆itim Okulu ve Yetiştirme Yurdu" adını almıștır. Okulda ilk ve orta öğretime ek olarak, Trikotaj-Çiçekcilik-Daktilografi-Biçki-HalıcılıkFotoğrafçlık, Dikiș vd. el işleride öğretilmektedir. Aynı zamanda cocuklarin fizik tedavileri, ameliyatları ve suni organ takılması ve diğer tıbbi tedavileride okulda yaptırılmaktadır. Uyarlanmış beden eğitim dersi hariç ortopedik özuirlüler okulunda normal ilk ve ortackul programları aynen uygulanmaktadir.

1981-1982 öğretim yllinda okula devam eden öğrenci sayısı 180 dir. 